\title{
THERMAL SIMULATION SOFTWARE BASED ON EXCEL FOR SPACECRAFT APPLICATIONS
}

\author{
Murat BULUT \\ Turksat Satellite Communication Cable TV and Operations Joint Stock Co., Satellite Programs Directorate, \\ Golbasi, Ankara, Turkey \\ muratbulut@turksat.com.tr
}

(Geliş/Received: 15.12.2017; Kabul/Accepted in Revised Form: 04.04.2018)

\begin{abstract}
In the early deveopment stage of the spacecraft program, it is desirable to establish thermal analysis results within a couple of minutes. Therefore, an in-house thermal simulation software (TSS) tool was developed to predict the temperature quickly and accurately. The TSS tool is not intended to replace the current commercial simulation tools for spacecraft thermal behavior. Its purpose is to allow fast assessment and comparison of technical solutions. In this study, a simple TSS tool model (7 nodes) was developed to execute quick trade studies, compare temperature, and compare computation time to that using ThermXL and SatTherm software tools. The TSS software provides satisfactory temperature results in significantly less computational time than ThermXL or SatTherm.
\end{abstract}

Key Words: Thermal analysis, Thermal design, Thermal control, Spacecraft

\section{Uzay Araç Uygulamaları için Excel üzerinde Isıl Simulasyon Yazılımı}

ÖZ: Uzay aracı programının erken sayfasında 1 sıl analiz sonuçlarının bir kaç dakika içerisinde sonuçlanması istenilmektedir. Bu yüzden, ısıl simulasyon yazılım aracı sıcaklıkları kısa bir süre içerisinde tahmin etmek için geliştirilmiştir. Isıl simulasyon yazılımı aracı, kritik tasarımı gözden geçirmek için kullanılan detaylı simülasyon için gerekli ticari yazılım aracının yerini almak için tasarlanmamıştır. Amacı, teknik çözümlerin hızlı bir şekilde değerlendirilmesini ve karşılaştırılmasını sağlamaktır. Bu çalışmada, hızlı bir kar zarar çalı̧̧ması yapmak için TSS araç modeli (7 düğümlü) geliştirildi ve ThermXL ve SatTherm yazılım araçlarını kullanarak sıcaklık sonuçları ve hesaplama süresi karşılaştırıldı. TSS yazılım aracı, ThermXL ve SatTherm'e karşılaştırıldığında daha düşük hesaplama zamanında yeterli sıcaklık sonuçları sağlar.

Anahtar Kelimeler: Isıl analiz, Isıl tasarm, Isll kontrol, Uzay aracı

\section{INTRODUCTION}

Maintaining spacecraft temperature is extremely important for a successful space mission. In a spacecraft, every component requires temperature limitations which include operational and nonoperational (survival) temperature range. Thermal control system of a spacecraft is responsible for maintaining temperatures within the required temperature limitations. Component temperatures and thermal analyses are evaluated during the multiple stages of spacecraft design. Therefore, there are many commercial software tools in the aerospace industry to support detailed analysis of components, sub-systems, and systems. Examples of the software tools are Thermal Desktop by Cullimore \& Ring Technology, Thermica by Systema (Airbus Defence and Space), and ESATAN-TMS by ITP Group. All of these tools are well suited to the requirements of later phases of the spacecraft process. They are far from 
optimal during the early phase of the spacecraft thermal design. It is also difficult to build accurate and safe spacecraft models in a short period of time when computations are performed by humans. Therefore, in-house TSS tools are developed by companies within the space industry in order to simplify the process of spacecraft thermal analysis such as ThermXL and SatTherm. ThermXL was released in July 2000 and provided the first thermal analysis tool to be fully integrated within a spreadsheet (Thomas et al., 2001). A simple ThermXL model was developed to exercise quick trade studies to predict the temperatures. The total number of nodes was 10. ThermXL runs on Microsoft Excel. Previously, Excel was limited to 255 columns per spreadsheet. This, in turn, Excel was limited number of 254 nodes. ThermxL provides an environment for constructing a lumped-parameter thermal analysis network, as well as built-in routines for solving the analysis in both transient and steady state (using the well-known finite difference method). SatTherm is a MATLAB and Excel-based thermal analysis tool developed for small spacecraft as a collaborative effort between the Mission Design Center at NASA Ames and San Jose State University (Allison et al., 2009). The total number of nodes was 10. SatTherm uses the finite difference method to solve for time-dependent temperature of spacecraft components. Thermal Desktop, Thermica, and ESATAN-TMS can have three dimensional regions. Unlike ThermXL, SatTherm and TSS are limited to two dimensional nodal regions.

Although thermal engineers in the aerospace industries and universities rely on the commercial analysis tools, they still can develop in-house thermal software tool. Richmond presented the Adaptive Thermal Modeling Tool (ATMT) (Richmond, 2010). ATMT is a MATLAB-based thermal modeling tool designed for smallsat applications. ATMT is a free for educational institutes. Shirazi and Mirshams developed Satellite Thermal Modeling Software (STMS) based on MATLAB GUI in order to design and analyze the satellite model (Shirazi and Mirshams, 2013). It compares the thermal analysis of a satellite with specific configuration and thermophysical properties in STMS software and SatTherm software. Error calculations for ten random data were presented (Diaz-Aguado et al., 2009). The maximum and minimum errors were $3.953 \%$ and $0.158 \%$ (Shirazi and Mirshams, 2013).

Space industries have developed in-house software tools to help support the analysis. This introduces an additional effort required to maintain and validate the tools. Even then they often need to be modified for anything other than very standard applications. Commercial software tools in space industries have distinct advantages and disadvantages. The advantages of using commercial software tools are accuracy, modeling flexibility, and pre and post processing capabilities. The disadvantages are cost, modeling time, and complexity (Richmond, 2010).

Many of the software tools used for spacecraft design and analysis have considerable cost and complexity. TSS is an alternative thermal analysis tool developed for in-house spacecraft software tool. TSS can quickly approximate the average temperature of spacecraft components at the beginning of the spacecraft project.

\section{THERMAL ANALYSIS}

Thermal control is a process of energy management in which environmental heating plays a major role. The principal forms of environmental heating in orbit are direct sunligt (solar), sunlight reflected off the Earth (albedo), and Earth Infrared (IR) emitted by Earth (Blom et al., 2006). The energy balance between the spacecraft and space is shown in Figure 1. 


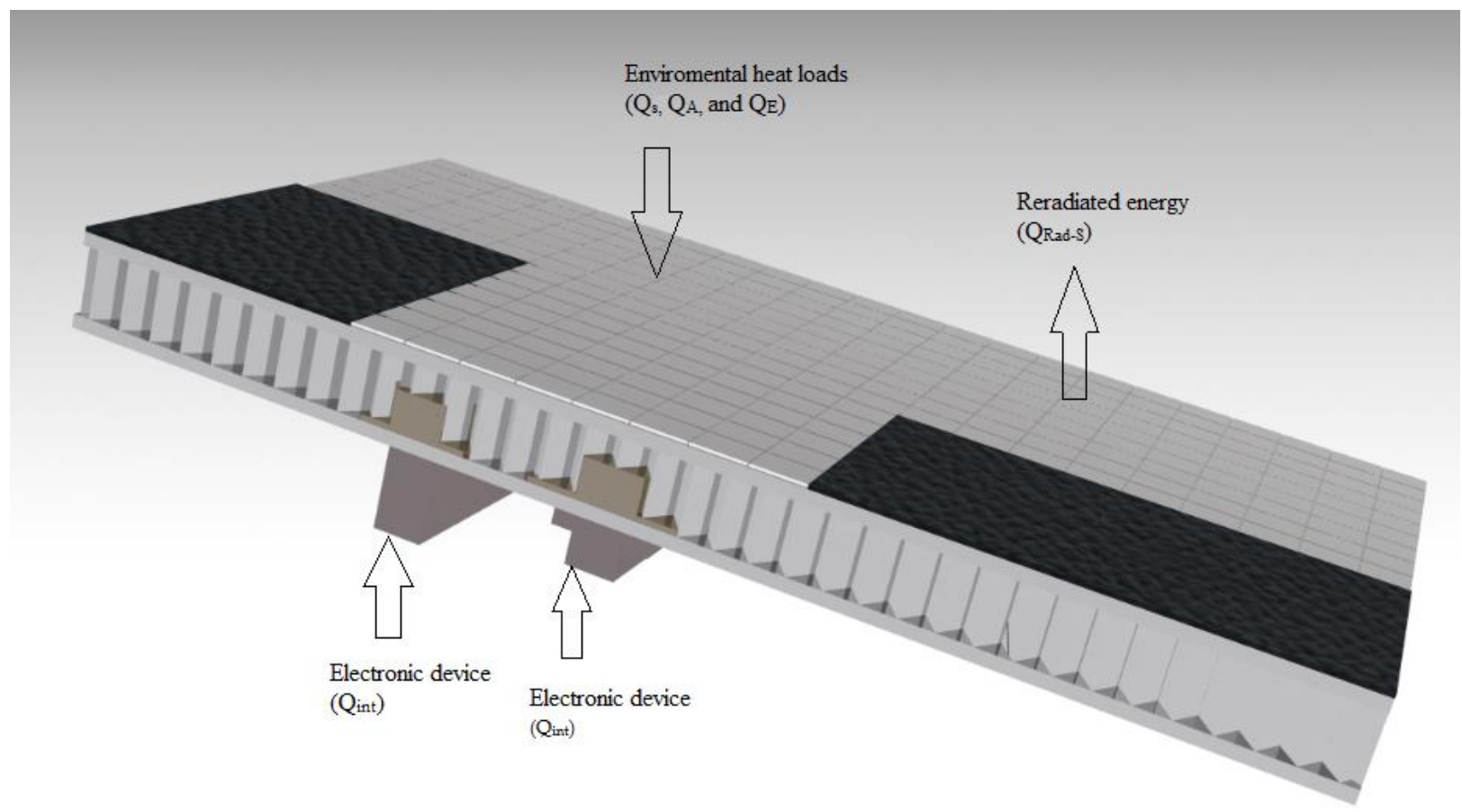

Figure 1. Energy balance between spacecraft and space

Spacecraft temperature energy (heat) is obtained from the solution of balance equations. The energy equation is written for each part of the satellites. The equilibrium temperature is obtained from condition $Q_{i n}=Q_{\text {out }}$. Energy balance for spacecraft;

$$
Q_{S}+Q_{A}+Q_{E}+Q_{\text {int }}=Q_{\text {Rad }-S}
$$

Based on equation (1); left side of equation shows heat load produced by electronic device $\left(Q_{\text {int }}\right)$ and absorbed by spacecraft $\left(Q_{S}, Q_{A}, Q_{E}\right)$. The right side equation (2), shows heat load received by spacecraft $\left(Q_{\text {Rad }-S}\right)$.

$$
\left(A_{S} q_{S}+A_{A} q_{A}\right) \alpha+A_{E} q_{E} \varepsilon+Q_{\mathrm{int}}=A_{\text {surfac }} \sigma\left(T_{r}^{4}-T_{s}^{4}\right) \mathcal{\varepsilon}
$$

$A_{S}, A_{A}$, and $A_{E}$, are the projected areas receiving Solar, Albedo, and Earth. Asurface is the spacecraft raditor area. Environmental heat loads are heat received directly from the Sun, Albedo contribution, and Earth radiation contribution.

Heat flux is defined as the amount of direct solar radiation by the spacecraft is defined as

$$
Q_{S}=q_{S} \alpha A_{S}
$$

Where $q_{S}$ is Sun flux, $\alpha$ is absorptivity, and $A_{S}$ is surface area from Sun radiation.

The amount of reflected heat flux that is absorbed by the satellite is

$Q_{A}=q_{A} \alpha A_{A}$ 
Where $q_{A}$ is albedo flux, $\alpha$ is absorptivity, and $A_{A}$ is surface area from earth (albedo) radiation.

The total Earth radiation absorbed by the spacecraft is given by

$Q_{E}=q_{E} \alpha A_{E}$

Where $q_{E}$ is Earth flux, $\alpha$ is absorptivity, and $A_{E}$ is surface area from earth infrared radiation.

The right side, equation (2), is the heat rejected from the radiator surface.

$Q_{\text {Rad-S }}=\sigma\left(T_{r}^{4}-T_{s}^{4}\right) \varepsilon A_{\text {surface }}$

where $\sigma$ is Stefan-Boltzman constant $\left(5.699^{*} 10^{-8} \mathrm{~W} / \mathrm{m}^{2} \mathrm{~K}^{4}\right) . T_{r}$ is radiator temperature. $T_{s}$ is space temperature. $\varepsilon$ is emmisivity. $A_{\text {surface }}$ is the spacecraft radiator area.

\section{OVERVIEW OF THERMAL SIMULATION SOFTWARE}

The TSS tool is a thermal model based on the Microsoft ${ }^{\circledR}$ Excel spreadsheet program. This is the mathematical approach used for predicting temperatures in a small thermal model. The TSS tool handles conduction and radiation. Thermal model consists of 7 nodes. The thermal model network is defined within the excel spreadsheet. Individual worksheets are provided to hold the node information, conduction matrix, radiation matrix and Sun impact. With the TSS tool, each spacecraft component should be modeled by a single node, not split into multiple nodes.

\section{THE THERMAL SIMULATION SOFTWARE STRUCTURE}

The TSS tool is developed in-house to predict the temperature at the early stage of the spacecraft program. Thermal model consists of 7 nodes. The excel based user-interface has four pages of inputs in which the user can fully define the thermal model. Example screenshot of the TSS tool inputs is displayed in Figure 2. In general, yellow cells are inputs for user to define. Green cells are calculated based from the user's inputs. Figure 2 shows the screenshot of the first page of the TSS tool inputs. First page (input) is to specify absorptiviy $(\alpha)$, emmisivity $(\varepsilon)$, radiative surface $\left(A_{\text {surface }}\right)$, Sun factor $\left(q_{s, i}\right)$, space view factor $\left(F_{i j}\right)$, dissipation $\left(Q_{\mathrm{int} i j}\right)$, and initial temperature. The second page (conduction matrix) is to specify conductive conductance (CC). The third page (radiation matrix) is to specify radiative conductance (RC). Fourth page includes calculated values of Sun impact (SI). 


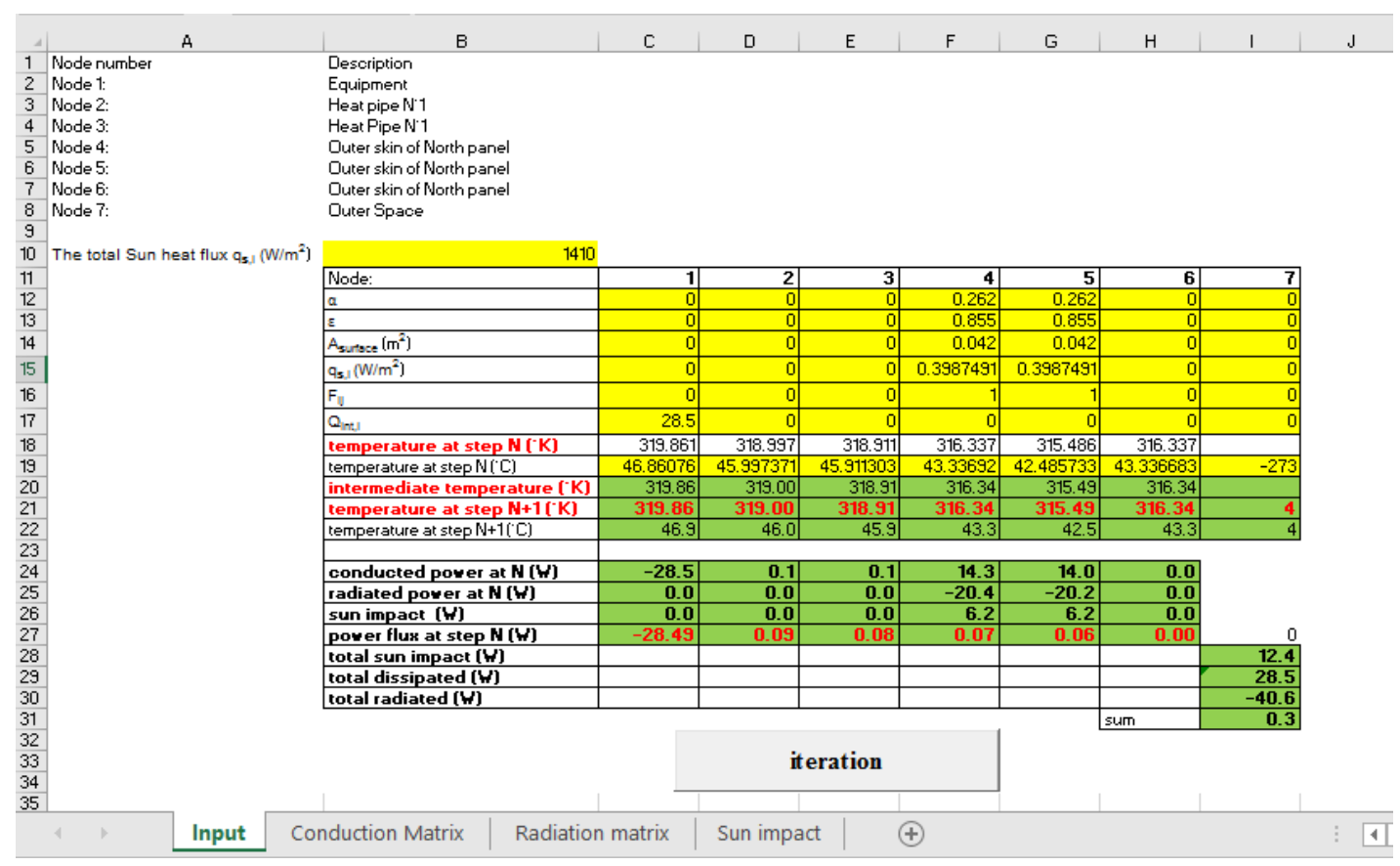

Figure 2. Screenshot of inputs of the TSS software tool

The subject of the TSS software tool is to calculate the temperature in ${ }^{\circ} \mathrm{C}$ of a thermal node. Thermal node is linked to a physical entity. It can be the baseplate of a piece of equipment, the wall of a heat-pipe, or deep space. The heat flux occurring through conduction $\left(q_{C}\right)$ between two nodes is expressed as follows:

$q_{C}=C_{i j} x\left(T_{j}-T_{i}\right)$

$C_{i j}\left(\mathrm{~W} /{ }^{\circ} \mathrm{K}\right)$ is conduction coefficient between node " $\mathrm{i}$ " and node " $\mathrm{j}$ ". $\mathrm{T}_{\mathrm{i}}$ is temperature of node " $\mathrm{i}$ " in ${ }^{\circ} \mathrm{K} . T_{j}$ is temperature of node " $\mathrm{j}$ " in ${ }^{\circ} \mathrm{K}$. The heat flux occurring through radiation $\left(q_{R}\right)$ between two nodes is expressed as follows:

$q_{R}=\left(R_{j i} x T_{j}^{4}\right)-\left(R_{j i} x T_{i}^{4}\right)$

$R_{i j}(\mathrm{~W} / \mathrm{o} \mathrm{K})$ is radiation coefficient between node " $\mathrm{i}$ " and node " $\mathrm{j}$ ".

The energy balance for node " $\mathrm{i}$ " can be written as follows:

$0=\left(\sum_{j} C_{i j} x\left(T_{j}-T_{i}\right)\right)+\left(\sum_{j} R_{j i} x\left(T_{j}^{4}-T_{i}^{4}\right)\right)+q_{\mathrm{int} i}+q_{s, i}$

If $\mathrm{n}$ is the iteration step number $\mathrm{n}$ and $\mathrm{n}+1$ is the next iteration step, one can write, with a great probability convergence.

$0=\left(\sum_{j} C_{i j} x T_{j, n}\right)-\left(\sum_{j} C_{i j} x T_{i, n+1}\right)+\left(\sum_{j} R_{j i} x T_{j, n}^{4}\right)-\left(\sum_{j} R_{j i} x T_{i, n}^{3} x T_{i, n+1}\right)+q_{\mathrm{int} i}+q_{s, i}$

and hence: 


$$
T_{i, n+1}=\frac{\left(\sum_{j} R_{j i} x T_{j, n}^{4}\right)+\left(\sum_{j} C_{i j} x T_{j, n}\right)+q_{\mathrm{int} i}+q_{s, i}}{\left(\sum_{j} R_{j i} x T_{i, n}^{3}\right)+\left(\sum_{j} C_{i j}\right)}
$$

If $\mathrm{n}$ is the iteration step number $\mathrm{n}$ and $\mathrm{n}+1$ the next iteration step, one can write great probability of convergence. Convergence is eased by the fact that when $T_{i, n+1}$ is very near from $T_{i, n}$. The effects on the energy balance of the decomposition are becoming $0 . q_{\mathrm{int} i}$ is the heat dissipation in node " $\mathrm{i}$ ". $q_{\mathrm{int} i}$ is positive for standard electronic equipment. $q_{s, i}$ is the incident Sun heat flux. It is always positive.

\section{AN EXAMPLE OF THE APPLICATION OF TSS TOOL}

In this section, one example is presented by using TSS tool. Figure 3 and Figure 4 show the model which was studied. The thermal model includes in 6 nodes. Node 1 is electronic equipment. Node 2 is an evaporation side of the heat pipe. Node 3 is a condenser side of the heat pipe. Node 4 is a radiative panel outer surface covered by optical solar reflector (OSR) which directly under heat pipe. Node 5 is other radiative panel outer surface covered by OSR. Node 6 is deep space and with constant temperature of 4 ${ }^{\circ} \mathrm{K}$.

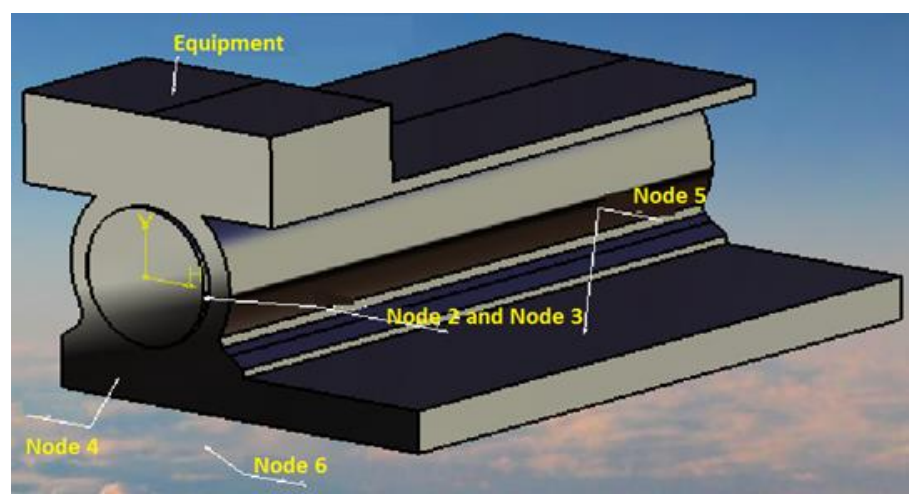

Figure 3. The model configuration (3D view) (Arslantas et al., 2016; Arslantas et al., 2017 )

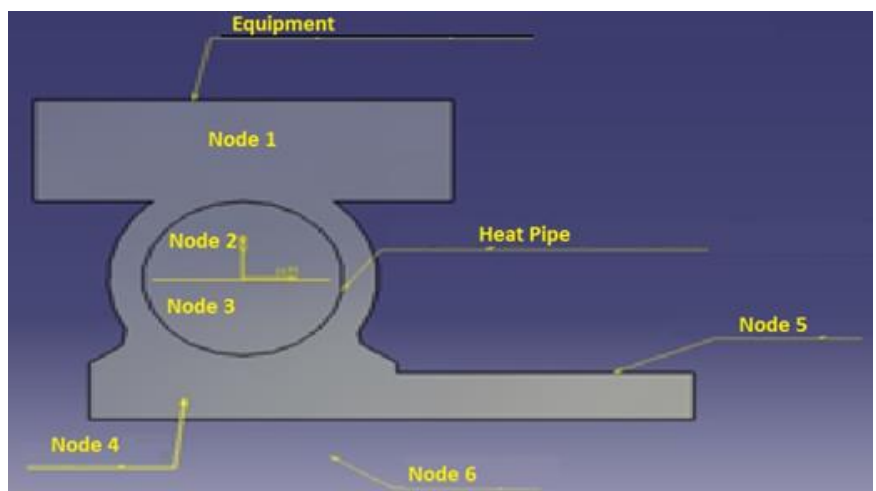

Figure 4. The model configuration (front view) (Arslantas et al., 2016; Arslantas et al., 2017)

Values used in the calculation for temperature parameter are shown in Table 1. The maximum, and minimum values shown in Table 1 were calculated by using the values shown in Table 2. Only heat load comes from Sun have taken into account in calculation because GEO satellites are $36.000 \mathrm{~km}$ from the Earth. Earth albedo and Earth IR values are considered zero. View factor was taken 1 in calculation. Stefan Boltzman constant $(\sigma)=5,67^{*} 10^{-8} \mathrm{~W} / \mathrm{m}^{2} / \mathrm{K}^{4}$ has been taken. To demonstrate the accuracy of the TSS 
software, the TSS software and ThermXL, the TSS software and SatTherm are both run through the identical simulations ( minimum, nominal, maximum).

Table 1. Thermal parameter values

\begin{tabular}{|l|c|ccc|}
\hline Parameter & Unit & \multicolumn{3}{|c|}{$\begin{array}{c}\text { Values } \\
\text { Nominal }\end{array}$} \\
& & Maximum \\
\hline Sun Intensity & $\mathrm{W} / \mathrm{m}^{2}$ & 1397 & 1418 & 1439 \\
Absorptivity & & 0,3589 & 0,37 & 0,3811 \\
Emissivity & & 0,7566 & 0,78 & 0,8034 \\
Radiation Area & $\mathrm{m}^{2}$ & 0,0475 & 0,05 & 0,0525 \\
Conductive & & & & \\
Conductance & $\mathrm{W} / \mathrm{K}$ & $18-135$ & $20-150$ & $22-165$ \\
Dissipation & $\mathrm{W}$ & 28,5 & 30 & 31,5 \\
\hline
\end{tabular}

Table 2 was taken from ECSS-E-30 Space Engineering Part 1A Mechanical- Part 1 Thermal Control document. The values on Table 2 were used in order to calculate the parameter inaccuracies.

Table 2. Parameter inaccuracies (ECSS, 2000)

\begin{tabular}{|l|cc|}
\hline Parameter & Unit & $\begin{array}{c}\text { ECSS } \\
\text { Standard }\end{array}$ \\
\hline Solar Intensity & $\mathrm{W} / \mathrm{m}^{2}$ & $+/-21$ \\
Absorptivity & & $+/-0,03 \%$ \\
Emissivity & & $+/-0,03 \%$ \\
Radiation Area & $\mathrm{m}^{2}$ & $+/-5 \%$ \\
Conductive & & \\
Conductance & $\mathrm{W} / \mathrm{K}$ & $+/-10 \%$ \\
Dissipation $(>\mathbf{1 0} \mathbf{W})$ & $\mathrm{W}$ & $+/-5 \%$ \\
\hline
\end{tabular}

Table 3 shows the thermal analysis conditions which are taken account during thermal analysis.

Table 3. Thermal analysis conditions

\begin{tabular}{|l|ccc|}
\hline Parameter & Maximum & Nominal & Minimum \\
\hline Solar Intensity & Max & Nominal & Min \\
Absorptivity & Max & Nominal & Min \\
Emissivity & Min & Nominal & Max \\
Radiation Area & Min & Nominal & Max \\
Conductive & & & \\
Conductance & Min & Nominal & Max \\
Dissipation & Max & Nominal & Min \\
\hline
\end{tabular}

During the maximum condition, solar intensity, absorptivity and dissipation values are maximum values. On the other hand, emissivity, radiation area, and conductive conductance are minimum values. 


\section{RESULTS AND DISCUSSIONS}

Thermal analysis of the spacecraft is required to verify and refine the thermal design. It is used to predict temperature of the spacecraft in a known or assumed heating environment, using a steady state analysis.

In this study, maximum and minimum calculated temperatures are presented with the small thermal model by using the TSS tool, ThermXL, and SatTherm Software. The calculated temperature values are shown in Table 4. By using the TSS tool, temperatures are as follows. The highest temperature is $66,8^{\circ} \mathrm{C}$ at node 1 (equipment temperature) in the maximum condition. The highest temperature is 42,5 ${ }^{\circ} \mathrm{C}$ at node 5 (radiator temperature) in the minimum condition. The highest temperature difference between node 1 and node 5 is $5,9{ }^{\circ} \mathrm{C}$ in the maximum condition. The lowest temperature difference between node 1 and node 5 is $4,4{ }^{\circ} \mathrm{C}$. Between the maximum temperature and the minimum temperature at node is $19,9{ }^{\circ} \mathrm{C}$. Most electronic equipment operates below $85^{\circ} \mathrm{C}$. By using ThermXL software tool, the maximum and minimum temperatures are $62,8{ }^{\circ} \mathrm{C}$ at node 1 and $38,4{ }^{\circ} \mathrm{C}$ at node 5 . By using SatTherm software tool, the maximum and minimum temperatures were $63,7{ }^{\circ} \mathrm{C}$ at node 1 and $39,6^{\circ} \mathrm{C}$ at node 5 , respectively. The average computation time of the TSS tool, ThermXL, and SatTherm are $11,8,9$ seconds.

It can also be seen from Table 4 that the calculated temperature results varied greatly because of the parameters, shown in Table 3. It can be seen from Table 4 that all the temperatures are within the range of the allowable maximum temperature.

Table 4. Calculated temperature results

\begin{tabular}{|c|c|c|c|c|c|c|}
\hline & & \multirow{2}{*}{\multicolumn{5}{|c|}{ Node }} \\
\hline & & & & & \\
\hline \multirow[t]{2}{*}{ Software } & \multirow[t]{2}{*}{ Temperatures } & 1 & 2 & 3 & 4 & 5 \\
\hline & & \multicolumn{5}{|c|}{${ }^{\circ} \mathrm{C}$} \\
\hline \multirow{3}{*}{ TSS } & Maximum Temperature & 66,8 & 65,7 & 65,5 & 62,1 & 60,9 \\
\hline & Nominal Temperature & 56,6 & 55,6 & 55,5 & 52,5 & 51,5 \\
\hline & Minimum Temperature & 46,9 & 46 & 45,9 & 43,3 & 42,5 \\
\hline \multirow{3}{*}{ ThermXL } & Maximum Temperature & 62,8 & 61,7 & 61,5 & 58,1 & 56,9 \\
\hline & Nominal Temperature & 53,5 & 52,5 & 52,1 & 49,8 & 48,7 \\
\hline & Minimum Temperature & 43,8 & 42,7 & 42,5 & 39,4 & 38,4 \\
\hline \multirow{3}{*}{ SatTherm } & Maximum Temperature & 63,7 & 62,6 & 62,5 & 59,2 & 57,8 \\
\hline & Nominal Temperature & 54,6 & 53,8 & 53,6 & 50,7 & 49,6 \\
\hline & Minimum Temperature & 44,5 & 43,9 & 43,7 & 40,5 & 39,6 \\
\hline
\end{tabular}

\section{CONCLUSION}

In this study, the initial thermal performance of the sample model was presented with using the TSS tool at a steady state condition. All analysis conditions were run by using ThermXL and SatTherm software tools. The temperature results and computation time were compared to each other. The results of the initial analysis involving radiation and conduction of the sample model were represented.

The temperatures predicted by the TSS tool agreed with those predicted by ThermXL tool within 4 ${ }^{\circ} \mathrm{C}$ or less and SatTherm tool within $3{ }^{\circ} \mathrm{C}$ or less. The computation time of the TSS was 3 seconds longer than the computation time of ThermXL and 2 seconds longer than SatTherm. Because Excel re-calculates every cell when the number was modified, the solution time with the TSS tool, ThermXL, and SatTherm 
were noticeably slower than using the commercial softwares ( Thermal Desktop, Thermica, EsatanTMS).

The TSS tool is found to be a suitable tool for early phase thermal design and analysis. The thermal model development time is quick, simple, and intuitive as the design progresses. TSS tool enables quick turnaround result, which is suitable for parametric studies.

\section{REFERENCES}

Allison, C., Diaz-Aguado, M., Jaroux, B., 2009, "SatTherm: A Thermal Analysis and Design Tool for Small Spacecraft", 23 ${ }^{\text {rd }}$ Annual AIAA/USU Conference on Small Satellites, Logan, UT, USA, 10-13 August 2009.

Arslantas, E., Bulut, M., Sozbir, N., 2016, “Haberleşme Uydularında Belirsizlik Değerlerinin Isıl Kontrol Sistemine Etkisi", IV. Ulusal Havacllk ve Uzay Konferansı, Kocaeli, Turkey, 28-30 September 2016. (in Turkish)

Arslantas, E., Bulut, M., Sozbir, N., 2017, “The Effect of Uncertainty Values of Thermal Control System on GEO Satellites". $8^{\text {th }}$ International Conference on Recent Advances in Space Technologies-RAST 2017, Turkish Airforce Academy, Istanbul, 19-22 June 2017.

Blom, E., Narverud, E., Birkeland, R., 2006, Technical Specifications, pp. 25-29.

Diaz-Aguado, M.F., Ghassemieh, S., Van Outryve, C., Beasley, C., and Schooley, A., 2009, "Small ClassD Spacecraft Thermal Design, Test and Analysis- PharmaSat Biological Experiment", IEEE Aerospace Conference, Big Sky, MT, USA, 7-14 March 2009.

ECSS-E-30, 2000, Part 1A: Space Engineering, Mechanical-Part 1: Thermal Control, ESA Publications.

Richmond, J.A., 2010, Adaptive Thermal Modeling Architecture for Small Satellite Applications, Master of Science in Aeronautics and Astronautics at Massachusetts Insitute of Technology, June 2010.

Shirazi, A., Mirshams, M., 2013, "Software Development for Satellite Thermal Design", Applied Mechanics and Materials, Vol. 390, pp 703-707.

Thomas, J., Robson, A., Price, S., 2001, "Spreadsheet Analysis for Early Phase Thermal Design", 31st International Conference on Environmental Systems, Orlando, FL, USA, 9-12 July 2001. 